\title{
Renewed Archaeological Investigations at the Sanders Site (41LR2), Lamar County, Texas
}

Timothy K. Perttula

Heritage Research Center, Stephen F. Austin State University

Bo Nelson

Heritage Research Center, Stephen F. Austin State University

Mark Walters

Heritage Research Center, Stephen F. Austin State University

Follow this and additional works at: https://scholarworks.sfasu.edu/ita

Part of the American Material Culture Commons, Archaeological Anthropology Commons, Environmental Studies Commons, Other American Studies Commons, Other Arts and Humanities Commons, Other History of Art, Architecture, and Archaeology Commons, and the United States History Commons

Tell us how this article helped you.

This Article is brought to you for free and open access by the Center for Regional Heritage Research at SFA ScholarWorks. It has been accepted for inclusion in Index of Texas Archaeology: Open Access Gray Literature from the Lone Star State by an authorized editor of SFA ScholarWorks. For more information, please contact cdsscholarworks@sfasu.edu. 
Renewed Archaeological Investigations at the Sanders Site (41LR2), Lamar County, Texas

\section{Creative Commons License}

(c) (1) (9)

This work is licensed under a Creative Commons Attribution-NonCommercial 4.0 International License 


\title{
Renewed Archaeological Investigations at the Sanders Site (41LR2), Lamar County, Texas
}

\author{
Timothy K. Perttula, Bo Nelson, and Mark Walters
}

\section{INTRODUCTION}

At the request of one of the landowners, Ms. Julia Crawford, renewed archaeological investigations took place at the renowned Sanders site (41LR2) (Krieger 1946, 2000) in November 2013. These investigations consisted solely of a pedestrian survey of the main part of the Sanders site - the location of two ancestral Caddo earthen mounds and associated habitation deposits - on a broad alluvial terrace ( $450 \mathrm{ft}$. amsl) of the Red River (Figure 1), in conjunction with a surface collection of observed material culture remains. Other recent archaeological investigations at the Sanders site have taken place more than ca. $400 \mathrm{~m}$ south of the main part of the site, at the extreme southern part of the site, on a higher (470-480 ft. amsl) alluvial terrace of the river (see Carpenter 2011; Perttula and Marceaux 2011; Peyton 2013).

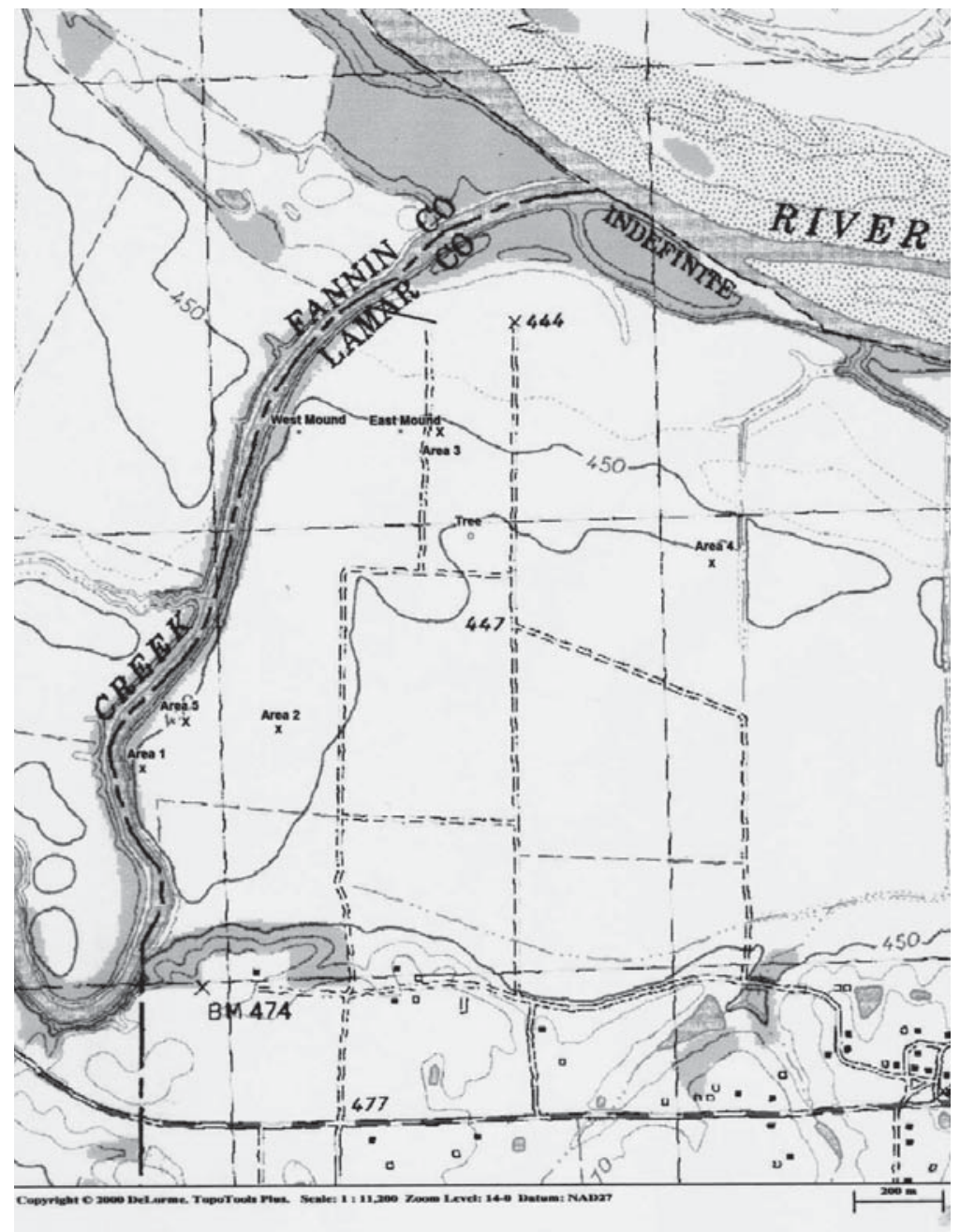

Figure 1. November 2013 surface collection areas at the Sanders site (41LR2). 


\begin{abstract}
AREAS
Seven different areas with concentrations of artifacts on the surface were identified during the November 2013 investigations. This includes the East (Mound No. 1, see Krieger 1946:Figure 9) and West (Mound No. 2) mounds on the northern part of the alluvial terrace, as well as Areas 3 and 4 on this part of the terrace (see Figure 1). The other three surface areas (Areas 1,2, and 5) are located on the southern part of the alluvial terrace, near Bois D'Arc Creek (see Figure 1).
\end{abstract}

\title{
MATERIAL CULTURE REMAINS
}

\section{Lithic Artifacts}

A total of 86 chipped stone or lithic artifacts was collected from six of the seven areas; Area 4 had no lithic artifacts visible on the surface during our investigations (Table 1). These artifacts are rather evenly distributed across the various surface collection areas.

Table 1. Lithic artifacts from surface collection areas at the Sanders site.

\begin{tabular}{lccccccrc}
\hline Area & AP & S & FT & FT/Drill & Bif. & Core & LD & N \\
\hline West Md. & 1 & 2 & - & - & - & - & 7 & 10 \\
East Md. & 1 & - & 1 & - & - & - & 11 & 13 \\
Area 3 & - & - & 3 & - & 1 & 1 & 14 & 19 \\
Area 4 & - & - & - & - & - & - & - & - \\
Area 1 & 1 & 1 & - & - & - & 2 & 17 & 21 \\
Area 2 & - & 2 & 3 & 1 & 1 & - & 5 & 12 \\
Area 5 & - & - & - & - & - & 1 & 10 & 11 \\
\hline Totals & 3 & 5 & 7 & 1 & 2 & 4 & 64 & 86 \\
\hline
\end{tabular}

$\mathrm{AP}=$ arrow point; $\mathrm{S}=$ scraper; $\mathrm{FT}=$ flake tool; FT/Drill=flake tool/drill; Bif.=biface; $\mathrm{LD}=$ lithic debris

The three arrow points include a gray chert arrow point blade fragment from Area 1 (Figure 2i), a gray novaculite tip and blade fragment from the East Mound (Figure 2c), and a triangular arrow point of a translucent gray chert from the West Mound area (Figure 2a); the latter is likely associated with the late 17 th-early 18th century occupation of the Sanders site. Arrow points of similar form from contemporaneous East Texas sites have been identified as Fresno and Maud points (Harris et al. 1965:Figure 1b-e; Jelks 1967:Figure 68a-g, i).

Scraping tools and flake tools are relatively common in the lithic assemblage, especially in Areas 2 and 3 (see Table 1). They include flake tools with unilateral retouched/use worn areas $(n=6)$, bilateral retouched/ use worn areas $(n=1)$; a flake with unilateral retouched/use worn areas and a drill $(n=1$, see Figure $2 h)$, and side scrapers $(n=5)$ (see Figure $2 b, d, f-g, j)$. These tools are made from high-quality lithic raw materials available as pebbles and cobbles in Red River gravels, including:

- white chert $(\mathrm{n}=1)$

- brown chert $(\mathrm{n}=2)$

- black chert $(n=1)$

- light gray chert $(\mathrm{n}=1)$ 


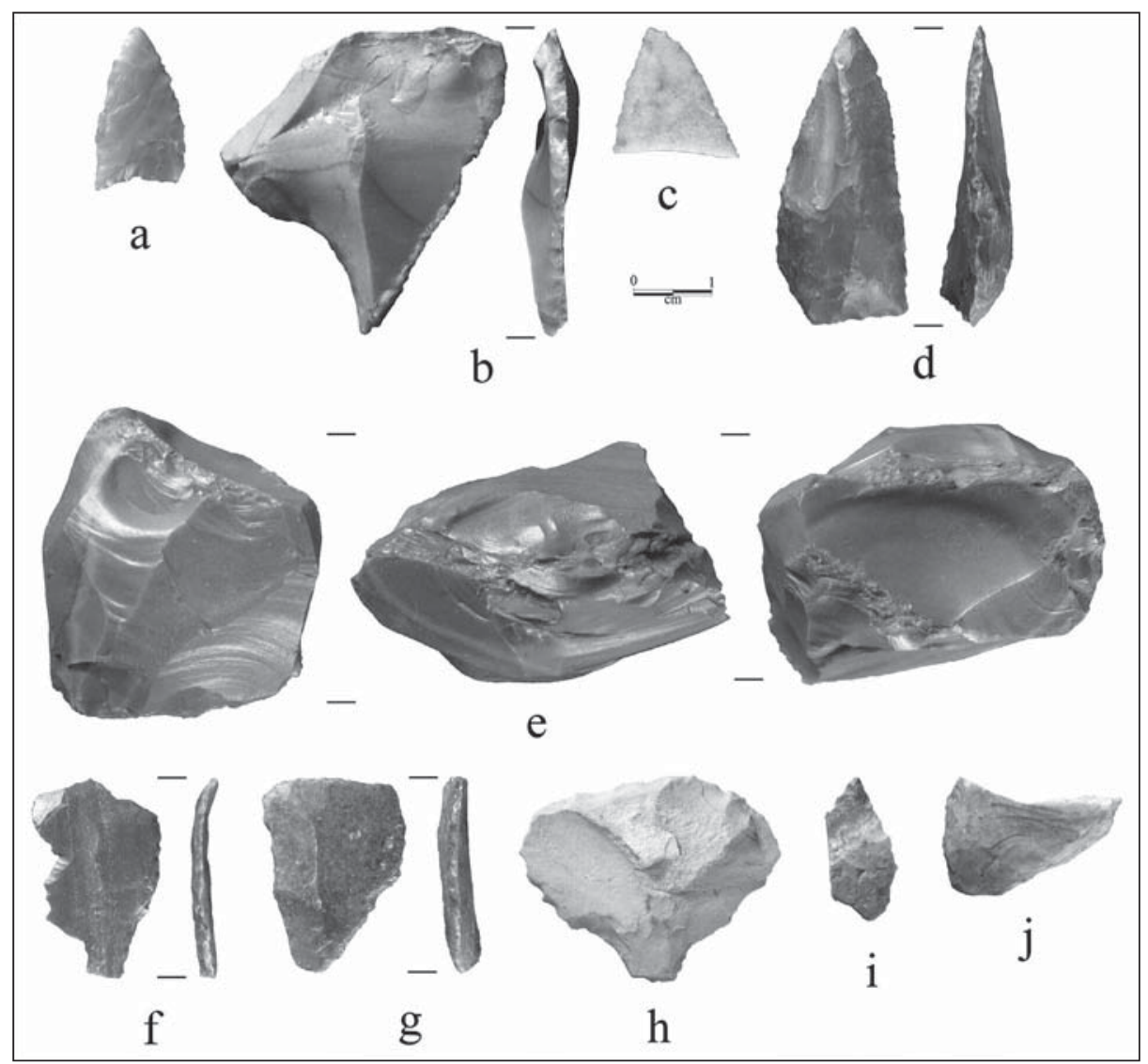

Figure 2. Chipped stone tools from the Sanders site: a, c, i, arrow points; b, d, scrapers; e, core; f-g, j, flake tools; h, drill.

- light red chert $(\mathrm{n}=1)$

- very dark grayish-brown chert $(n=3)$

- gray chert $(\mathrm{n}=1)$

- dark gray chert $(\mathrm{n}=2)$

- grayish-yellow chert $(\mathrm{n}=1)$

The two bifaces are thick early stage forms, made from a dark grayish-brown chert (Area 3) and quartzite (Area 2). These are likely the discarded products of dart point manufacture from earlier, pre-ca. A.D. 700 occupations at the Sanders site.

The cores are on pebbles and small cobbles likely the result of their reduction to produce usable flakes for arrow point and flake tool/scraper production. The cores from Area 1 are a multiple platform flake core of light gray chert (see Figure 2e) and a quartzite core fragment; the Area 3 core is a bipolar core of a dark grayish-brown chert; and the core from Area 5 is a multiple platform core of a dark grayish-brown chert.

The lithic debris is also primarily of high-quality chert raw materials, although quartzite raw materials were also commonly knapped, and the proportion of cortical flakes (42\%) is considerable among the lithic debris as a whole, indicating the knapping and reduction of local raw materials on the site during the ancestral Caddo occupation. The lithic raw materials represented in the lithic debris are: white chert $(n=1)$, gray chert $(\mathrm{n}=3,33 \%$ cortical); light gray chert $(\mathrm{n}=2,50 \%$ cortical), dark brown chert $(\mathrm{n}=3)$, very dark grayish-brown chert $(n=3)$, grayish-brown chert $(n=3,67 \%$ cortical), yellow chert $(n=1,100 \%$ cortical), black chert $(n=5$, $20 \%$ cortical), grayish-black chert $(n=1)$, brown chert $(n=3,67 \%$ cortical $)$; reddish-brown chert $(n=2,100 \%$ cortical), reddish-gray chert $(n=1,100 \%$ cortical), light brown chert $(n=1)$, dark gray chert $(n=5,40 \%$ corti- 
cal), brownish-gray chert $(n=3,33 \%$ cortical $)$, very dark gray chert $(n=6,67 \%$ cortical), bluish-gray chert $(n=1)$, gray novaculite $(n=1)$, light gray novaculite $(n=2)$, chalcedony $(n=2,50 \%$ cortical $)$, a greenish-gray quartzite $(n=1)$, quartzite $(n=13,54 \%$ cortical), and petrified wood $(n=1,100 \%$ cortical). In summary, approximately $68 \%$ of the lithic debris from the different surface areas at the Sanders site is from chert raw materials, $22 \%$ of the lithic debris is quartzite, $5 \%$ is novaculite, $3 \%$ is chalcedony, and $2 \%$ are petrified wood.

\section{CERAMIC SHERDS}

A total of 152 ceramic sherds were collected from the seven areas at the Sander site. They are concentrated particularly around the East and West Mounds on the northern part of the alluvial terrace, and in Areas 2 and 5 in the southern part of the landform (Table 2). The plain to decorated sherd ratio is a high 7.4:1, consistent with other pre-A.D. 1300 sites in this part of the Red River basin (Perttula 2013:9-10).

Table 2. Ceramic sherds from surface collection areas at the Sanders site.

\begin{tabular}{lccccc}
\hline Area & Plain rim & Plain body & Base sherd & $\begin{array}{c}\text { Decorated } \\
\text { sherds }\end{array}$ & N \\
\hline West Md. & - & 34 & 8 & 5 & 47 \\
East Md. & 1 & 21 & 2 & 6 & 30 \\
Area 3 & - & 12 & 2 & 1 & 15 \\
Area 4 & - & 3 & 1 & - & 4 \\
Area 1 & - & 4 & 1 & 4 & 32 \\
Area 2 & - & 16 & 2 & 1 & 19 \\
Area 5 & - & 117 & 16 & 18 & 152 \\
\hline Totals & 1 & 117 & & \\
\hline
\end{tabular}

The sherds are tempered primarily with grog (or crushed sherds), but several sherds are from vessels tempered either with bone $(n=13,8.6 \%)$ or shell $(n=9,5.9 \%)$. The bone-tempered sherds are from the East Mound ( $n=3)$, West Mound ( $n=6)$, Area $2(n=1)$, Area $3(n=1)$, and Area $5(n=2)$, in the northern and southern parts of the principal site on the lower alluvial terrace (see Figure 1). These sherds are likely representative of the ca. A.D. 1100-1300 Sanders phase occupation at the site. The sherds from shell-tempered vessels are more concentrated, being found in only Area $3(n=4)$, East Mound $(n=4)$, and the West Mound $(n=1)$. These shell-tempered sherds (cf. Harris et al. 1965:301; Krieger 1946:195). must mark at least one late 17th-early 18th century occupation at the Sanders site.

The grog- and bone-tempered decorated sherds include the following decorative elements: interior/ exterior red-slipped ( $n=3$, East Mound, Areas 3, and 4, Figure 3e); exterior red-slipped ( $n=1$, West Mound, Figure 3b); opposed engraved lines ( $n=2$, West Mound and Area 5); cross-hatched engraved zone ( $n=1$, West Mound, Figure 3a); singe tool punctate ( $\mathrm{n}=1$, East Mound); tool punctated rows ( $\mathrm{n}=3$, East Mound, West Mound, and Area 2, Figure 3d); fingernail punctated row ( $\mathrm{n}=1$, Area 2, Figure 3f); widely spaced parallel incised lines ( $\mathrm{n}=1$, East Mound); diagonal incised lines and a tool punctated row $(\mathrm{n}=1$, West Mound, Figure $3 c)$; curvilinear incised line ( $n=1$, Area 2); a straight incised line ( $n=1$, Area 2); and a straight appliqued ridge ( $n=1$, East Mound). The red-slipped sherds may be from Sanders Plain vessels, or the undecorated portions of Sanders Engraved vessels, while the engraved sherds are likely from Sanders Engraved vessels. The fingernail punctated sherd is from a Monkstown Fingernail Impressed jar, and the incised and incisedpunctated sherds may be from Canton Incised jars (see Krieger 1946:Plates 24-29). 


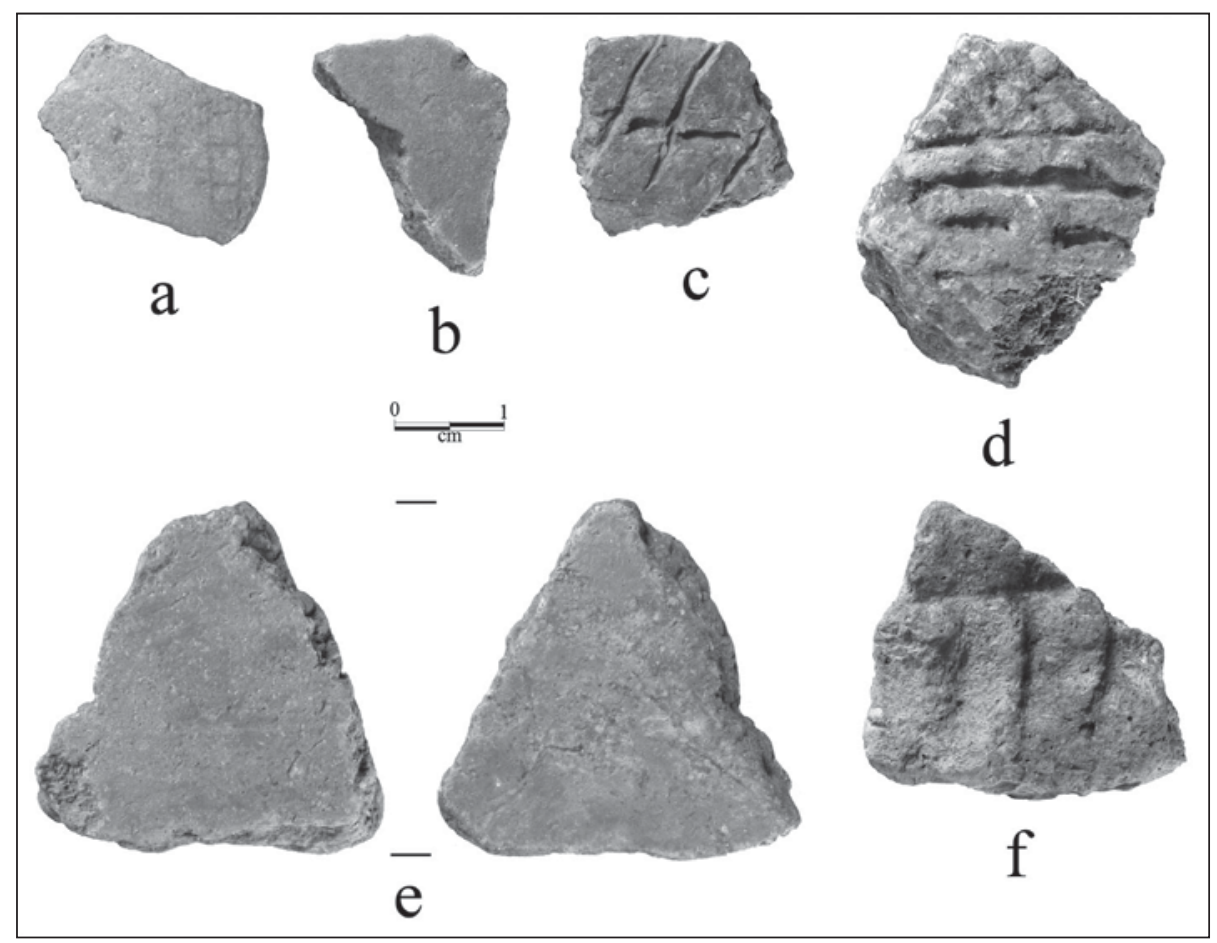

Figure 3. Decorated sherds from the Sanders site: a, engraved; b, e, red-slipped; c, incised-punctated; d, tool punctated; f, fingernail punctated.

The one decorated shell-tempered sherd is a body sherd from the East Mound area. It has a straight appliqued fillet on what must be the vessel body of an utility ware jar. The ceramic type is not known, unless the sherd is from a shell-tempered McKinney Plain vessel.

\section{OTHER ARTIFACTS}

Other recovered artifacts in the surface collection areas have been found only in the East and West Mound areas. This includes animal bones $(n=1$ in the East Mound area and five pieces in the West Mound area) and four pieces of daub/burned clay in the West Mound area.

\section{SUMMARY AND CONCLUSIONS}

Renewed archaeological investigations at the Sanders site (41LR2) in the Fall of 2013 led to the identification of seven different areas across the principal part of the site that have surface clusters of lithic and ceramic artifacts. Analysis of these artifacts suggest that a ca. A.D. 1100-1300 ancestral Caddo occupation covers a ca. 1000 x 300-1000 m area of an alluvial terrace overlooking the confluence of Bois D'Arc Creek and the Red River. This occupation is marked primarily by the distribution of grog-tempered and bonetempered plain and decorated ceramic sherds. A later occupation, probably dating from the late $17^{\text {th }}$ to the early $18^{\text {th }}$ century, is concentrated on the northwestern part of the site (around the East and West Mounds), and has plain and decorated shell-tempered ceramics and a triangular Fresno or Maud arrow point.

Hopefully, additional investigations can be carried out in the future at the Sanders site. These investigations might include remote sensing, additional surface inspections and artifact collections in habitation areas, and the initiation of excavations to sample and date habitation deposits and features. 


\section{ACKNOWLEDGMENTS}

We appreciate the access to the Sanders site provided by the landowner, Ms. Julia Crawford. Lance Trask prepared the artifact images for this article.

\section{REFERENCES CITED}

Carpenter, S.

2011 Investigations Conducted on the Crawford Property in Lamar County, Texas for the Keystone XL Pipeline. SWCA Environmental Consultants, Austin.

Harris, R. K., I. M. Harris, J. C. Blaine, and J. Blaine

1965 A Preliminary Archeological and Documentary Study of the Womack Site, Lamar County, Texas. Bulletin of the Texas Archeological Society 36:287-365.

Jelks, E. B. (editor)

1967 The Gilbert Site: A Norteno Focus Site in Northeast Texas. Bulletin of the Texas Archeological Society 37:1-248.

Krieger, A. D.

1946 Culture Complexes and Chronology in Northern Texas, with Extensions of Puebloan Datings to the Mississippi Valley. Publication No. 4640. The University of Texas, Austin.

2000 The Pottery of the Sanders Farm. In The 1931 Excavations at the Sanders Site, Lamar County, Texas: Notes on the Fieldwork, Human Osteology, and Ceramics, by A. T. Jackson, M. S. Goldstein, and A. D. Krieger, pp. 131-144. Archival Series 2. Texas Archeological Research Laboratory, The University of Texas at Austin.

Perttula, T. K.

2013 Analysis of the Prehistoric Artifact Assemblage of Ceramic and Lithic Artifacts from 41LR351, Lamar County, Texas. Journal of Northeast Texas Archaeology 39:7-41.

Perttula, T. K. and P. S. Marceaux

2011 Archeological Survey Investigations on the Crawford Property and a Portion of the T. M. Sanders Site (41LR2) in the New Proposed Right-of-Way for the Keystone XL Pipeline, Lamar County, Texas. Letter Report No. 280. Archeological \& Environmental Consultants, LLC, Austin.

Peyton, A.

2013 Interim Report: Results of Archaeological Significance Testing at the Sanders Site (41LR2), Lamar County, Texas. SWCA Environmental Consultants, Austin. 